\title{
PENGANGKUTAN BENIH IKAN BAWAL AIR TAWAR SELAMA 24 JAM DENGAN KEPADATAN BERBEDA MENGGUNAKAN BAKTERI PROBIOTIK
}

\section{TRANSPORT OF TAMBAQUI FISH FRY FOR 24 HOUR WITH DIFFERENT DENSITY RATES AND PROBIOTIC BACTERIA \\ TN Hartanto ${ }^{1}$, Rosmawati ${ }^{1}$, FS Mumpuni'}

${ }^{1}$ Jurusan Perikanan Fakultas Pertanian Universitas Djuanda Bogor, Jl. Tol Ciawi No. 1, Kotak Pos 35 Ciawi, Bogor 16720.

\begin{abstract}
The study was conducted at the Laboratory of Aquaculture Technology and Fishery Business, Djuanda University, Bogor from 8 to 30 February 2012. It was aimed at determining the highest density rate that could be used to transport tambaqui fish fry sized $3-5 \mathrm{~cm}$ placed in 5 liter plastic bags with probiotic bacteria concentration of $5 \mathrm{ml} /$ liter.

Probiotic bacteria (EM4) were mixed in the medium of 5 liter water in plastic bags. Fish fry sized $3-5 \mathrm{~cm}$ was then allocated into each bag with the density rates of 300, 400, and 500 fry. A completely randomized design with 4 treatments and 3 replicates was used. Treatments consisted of probitoc bacteria (EM4) inclusions. Measurements were taken on survival rate (SR) after the transportation process, SR after the fry was raised in 5 days, and water quality.

The results of this study indicate that the SR after the transport process showed significantly different $(\mathrm{P}<0.05)$. SR is highest after the transport process at the level of density 300 left / 5 liters is equal to $95.88 \%$. In further testing LSD, obtained results that each treatment is significantly different from one another. Highest SR after maintained for 5 days in an aquarium located on the density of 400 individuals / 5 liters is equal to $95.83 \%$. Based on the test analysis variance (ANOVA) at the level of 5\% survival rate of seedlings was not significantly different pomfret.

Survival was highest in the transport of Tambaqui Fish Fry for 24 hours was on solid stocking 300 fish / 5 liters with a SR of $95.88 \%$. Range of water quality is still good enough for the transport for 24 hours.
\end{abstract}

Key words: Survival rate, transport, stock density, tambaqui fish fry.

Penelitian ini dilakukan di Laboratorium Perikanan Universitas Djuanda Bogor dari tanggal 8 - 30 Februari 2012. Penelitian ini bertujuan untuk menentukan tingkat kepadatan tertinggi yang dapat digunakan untuk pengangkutan benih ikan bawal berukuran 3-5 cm dalam kantong-kantong plastik berisi $5 \mathrm{~L}$ air dengan konsentrasi bakteri probiotik $5 \mathrm{~mL} /$ liter.

Bakteri probiotik (EM4) dicampurkan ke dalam medium dalam kantong-kantong plastik berisi $5 \mathrm{~L}$ air. Benih ikan berukuran 3-5 $\mathrm{cm}$ ditempatkan ke dalam tiap kantong dengan tingkat kepadatan 300, 400, dan 500 ekor. Rancangan acak lengkap menggunakan 4 perlakuan dan 3 ulangan. Perlakuan terdiri dari larutan bakteri probiotik (EM4). Penentuan kelangsungan hidup (SR) dilakukan setelah proses pengangkutan, SR setelah benih dipelihara selama 5 hari, dan kualitas air.

Hasil penelitian menunjukkan bahwa SR setelah proses pengangkutan memperlihatkan perbedaan yang signifikan $(\mathrm{P}<0,05)$. SR tertinggi setelah proses pengangkutan terdapat pada tingkat kepadatan 300 ekor/ 5 L yaitu 95,88\%. Pada uji lanjut LSD, diperoleh hasil bahwa setiap perlakuan berbeda nyata satu sama lain. SR tertinggi setelah dipelihara selama 5 hari dalam akuarium terdapat pada kepadatan 400 ekor/ 5 L yaitu 95,83\%. Berdasarkan analisis ragam (ANOVA) pada level 5\%, tidak ada perbedaan yang nyata terhadap kelangsungan hidup ikan. 
Kelangsungan hidup tertinggi pada pengangkutan benih ikan bawal selama 24 jam terdapat pada kepadatan 300 ekor/ 5 L dengan SR 95,88\%. Kisaran kualitas air masih cukup baik selama pengangkutan 24 jam.

Kata kunci: Kelangsungan hidup, pengangkutan, benih ikan bawal, tingkat kepadatan.

\section{PENDAHULUAN}

Ikan Bawal air tawar mempunyai prospek yang baik dan berkelanjutan karena permintaan terhadap kebutuhan protein hewani yang murah dan mudah didapat terus terbuka. Ikan bawal air tawar digolongkan sebagai komoditas ikan konsumsi dan ikan hias. Ikan ini berasal dari Amerika Selatan yakni Brazil, Venezuela, dan Ekuador (Martin dan Gunzman, 1994). Kondisi perairan di Indonesia menunjang untuk pembudidayaan ikan bawal air tawar, karena merupakan daerah tropis. Suhu perairan di habitat asli ikan bawal air tawar yaitu 27,2 - 29,10 $\mathrm{C}$ (Eckman, 1987). Keuntungan lainnya, relatif lebih tahan terhadap penyakit dan kadar oksigen rendah (Lagler et.al, 1977).

Pengangkutan ikan dengan cara tertutup lebih memaksimalkan tempat jika dibandingkan dengan cara terbuka, namun pengangkutan cara tertutup ini kepadatan ikan yang diangkut masih rendah. Pada pengangkutan tertutup, menurut petani selama ini hanya bisa melakukan pengepakkan dengan kepadatan benih ikan bawal sebanyak 300 ekor berukuran 3-5 cm dalam 5 liter air. Kepadatan yang rendah dapat mengakibatkan biaya pengangkutan yang cukup tinggi, dan untuk menurunkan biaya pengangkutan yang tinggi salah satunya adalah dengan cara meningkatkan kepadatan ikan yang diangkut. Meningkatnya kepadatan ikan, akan berdampak pada media pengangkutan, yaitu penurunan kualitas air. Untuk menanggulangi kualitas air yang jelek, maka dalam pengangkutan ini digunakan bakteri probiotik pada media air. Menurut Verschuere et al. (2000) dan Moriarty (1999), probiotik dapat memperbaiki kualitas air.

Tujuan dari penelitian ini adalah untuk mengetahui berapa kepadatan tertinggi benih ikan bawal ukuran 3-5 cm dengan dosis bakteri probiotik $5 \mathrm{ml} / 5$ liter air yang digunakan pada pengangkutan dalam satu wadah plastik 5 liter, yang memberikan kelangsungan hidup tinggi dengan lama pengangkutan 24 jam.

\section{Materi}

\section{MATERI DAN METODE}

Penelitian ini dilaksanakan pada tanggal 8 Februari - 30 Februari 2012 bertempat di Laboratorium Teknologi Budidaya dan Bisnis Perikanan Universitas Djuanda, Bogor.

Alat yang digunakan dalam penelitian ini adalah kantong plastik dengan tebal $0,08 \mathrm{~mm}$, diameter $50 \mathrm{~cm}$ dan panjang $50 \mathrm{~cm}$, karet gelang, timbangan, serokan, akuarium dan kendaraan roda empat.

Bahan yang digunakan dalam penelitian ini adalah benih ikan bawal hidup dengan ukuran 3-5 cm, bakteri probiotik EM4 dan oksigen murni.

\section{Perlakuan}

Penelitian ini menggunakan rancangan acak lengkap (RAL) dengan empat perlakuan dan tiga kali ulangan. Perlakuan yang diberikan adalah kepadatan ikan yang berbeda, yaitu:

1) Perlakuan $A$ dengan kepadatan benih 300 ekor / 5 Liter

2) Perlakuan B dengan kepadatan benih 400 ekor / 5 Liter

3) Perlakuan $\mathrm{C}$ dengan kepadatan benih 500 ekor / 5 Liter

\section{Rancangan Percobaan}

Rancagan yang digunakan dalam penelitian ini adalah Rancangan Acak Lengkap (RAL) :

$$
\text { Yij }: \mu+\beta i+£ i j
$$

Keterangan : Yij : nilai pengamatan pada perlakuan ke- i ulangan ke- j

$\mu:$ nilai tengah dari pengamatan

$\beta \mathrm{i}$ : pengaruh dari perlakuan ke i 


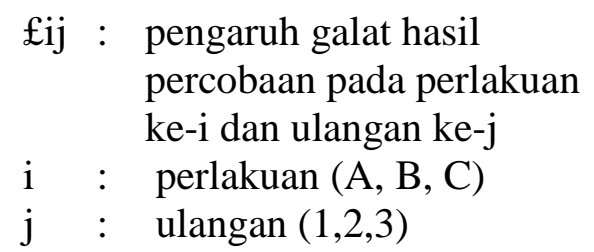

\section{Analisis Data}

Metode analisis data yang digunakan untuk SR adalah kuantitatif dan akan disajikan dalam bentuk statistik berupa analisis varian (anova). Apabila ada perbedaan yang nyata pada perlakuan, maka akan dilanjutkan dengan uji BNT.

\section{Prosedur Pelaksanaan}

Benih ikan yang akan diuji harus sehat dan tidak cacat. Hal ini dilakukan untuk mencegah agar benih ikan jangan sampai terlalu stress akibat penanganan selama pengepakan dan juga untuk memudahkan dalam proses pengepakan. Benih ikan yang berukuran 3-5 $\mathrm{cm}$ ini dimasukkan ke dalam kantong plastik dengan volume air 5 liter dengan kepadatan ikan 300 ekor, 400 ekor, 500 ekor dengan pemberian bakteri probiotik sesuai dosis yang telah ditentukan yaitu $5 \mathrm{ml}$ setiap perlakuan serta pemberian oksigen murni.

Kemudian kantong diikat dengan menggunakan karet, setelah pengepakan selesai, kemudian benih ikan dinaikkan ke atas kendaraan roda empat untuk diangkut selama 24 jam pada saat malam hari mulai dari pukul 05.00 WIB sampai pukul 05.00 WIB dengan tujuan agar kondisi suhu tetap stabil.

Rute perjalanan yang di tempuh adalah : Laboratorium Teknologi Budidaya dan Bisnis Perikanan Universitas Djuanda, - Jasinga Rangkas - Pandeglang - Laboratorium Teknologi Budidaya dan Bisnis Perikanan Universitas Djuanda yang ditempuh selama 24 jam. Setelah proses pengangkutan selesai, diambil data SR benih ikan bawal, setelah itu benih ikan dipelihara di dalam akuarium selama lima hari dan diambil data SR terakhir.

Tingkat kelangsungan hidup (SR) dihitung berdasarkan formula Effendi (1979), Yaitu:

$$
\mathrm{SR}=\mathrm{Nt} / \mathrm{No} \times 100 \%
$$

Keterangan:

$\mathrm{SR}=$ Tingkat kelangsungan hidup

$\mathrm{Nt}=$ Jumlah ikan pada akhir penelitian

$$
\text { No }=\begin{aligned}
& \text { Jumlah ikan pada awal } \\
& \text { penelitian }
\end{aligned}
$$

Pengamatan SR dilakukan dengan menghitung ikan yang hidup setelah proses pengangkutan selesai dan setelah ikan dipelihara selama lima hari di dalam akuarium Sebagai data penunjang dari penelitian ini diambil data kualitas air pada awal dan akhir penelitian. Data kualitas air yang dianalisis adalah DO, $\mathrm{CO}_{2}, \mathrm{pH}$, suhu dan $\mathrm{NH}_{3}$.

\section{HASIL DAN PEMBAHASAN}

Tingkat Kelangsungan Hidup (SR) Setelah

\section{Proses Pengangkutan}

Tingkat kelangsungan hidup terkecil pada pemberian probiotik $5 \mathrm{ml}$ dengan kepadatan 500 ekor / liter sebesar 69,73\%, sedangkan tingkat kelangsungan hidup tertinggi yaitu sebesar $95,88 \%$, pada tingkat kepadatan 300 ekor / 5 liter.

Berdasarkan uji analisis ragam (anova) pada taraf 5\% tingkat kelangsungan hidup benih ikan bawal berbeda nyata, artinya kepadatan memberikan pengaruh yang berbeda terhadap kelangsungan hidup benih ikan bawal pada proses pengangkutan selama 24 jam. Pada uji lanjut BNT, diperoleh hasil bahwa setiap perlakuan berbeda nyata satu dengan yang lainnya.

Pada pengamatan pertama, tingkat kelangsungan hidup tertinggi benih ikan bawal dalam proses pengangkutan selama 24 jam dengan dosis probiotik $5 \mathrm{ml}$ setiap wadah diperoleh pada perlakuan ( A 300 ekor / 5 liter ) sebesar 95,88\% dibandingkan dengan perlakuan ( B 400 ekor / 5 liter ) yaitu sebesar $82,66 \%$, perlakuan C ( 500 ekor / 5 liter ) yaitu sebesar 69,73\%. Perlakuan B lebih tinggi SR-nya dari pada perlakuan C, tetapi masih kurang baik jika di banding dengan perlakuan $\mathrm{A}$, hal ini mungkin dikarenakan terlalu padatnya benih ikan dalam wadah sehingga tingkat stress ikan meningkat dan mengganggu kelangsungan hidup benih ikan selama proses transportasi.

Untuk tingkat kelangsungan hidup (SR) tertinggi adalah pada perlakuan A yaitu sebesar $95,88 \%$, hal ini mungkin dikarenakan tingkat kepadatan masih dalam batas toleransi sehingga tingkat strees ikan kecil dan kesempatan ikan memanfaatkan oksigen lebih besar dan peningkatan kepadatan 
mempengaruhi proses fisiologis dan tingkah laku ikan terhadap ruang gerak selama proses pengangkutan berlangsung dan kondisi ikan dalam keadaan stress yang cukup tinggi.

Pada penelitian sebelumnya yang dilakukan oleh Zaenudin (2011) diperoleh SR tertingi pada kepadatan 400 ekor / 5 liter sebesar 95,71\% menggunakan dosis probiotik $5 \mathrm{ml}$ dengan lama pengangkutan 10 jam.

Adanya perbedaan kepadatan yang memberikan SR tertinggi antara penilitian ini dengan penelitian yang dilakukan oleh Zaenudin (2011), hal ini disebabkan perbedaan waktu pengangkutan. Penelitian ini lama pengangkutan yang dilakukan lebih lama yaitu 24jam sedangkan yang dilakukan Zaenudin selama 10 jam. Bila dibandingkan dengan kepadatan sebesar 400 ekor / 5 liter pada penelitian ini, dimana diperoleh SR 82,66 \%, lebih kecil dibandingkan penelitian Zaenudin yaitu sebesar $95,71 \%$.

\section{Tingkat Kelangsungan Hidup (SR) Setelah Dipelihara Selama Lima Hari Dalam Akuarium}

Data awal SR dihitung dari jumlah benih ikan yang hidup pada akhir pengangkutan. Hasil pengamatan didapat rata-rata SR terbesar pada perlakuan B yaitu sebesar 95,83\%, dan SR terkecil pada perlakuan $\mathrm{C}$ yaitu $94,13 \%$.

Berdasarkan uji analisis ragam (anova) pada taraf 5\%, tingkat kelangsungan hidup benih ikan bawal tidak berbeda nyata. Artinya perlakuan tingkat kepadatan 300 ekor / 5liter, 400 ekor / 5 liter dan 500 ekor / 5 liter tidak memberikan pengaruh yang berbeda terhadap tingkat kelangsungan hidup benih ikan bawal yang dipelihara selama 5 hari dalam akuarium dengan pemberian probiotik sebanyak $5 \mathrm{ml}$.

Pada pengamatan selanjutnya (benih ikan dipelihara selama lima hari dalam akuarium), diperoleh data SR pada saat pemeliharaan dalam akuarium tidak berbeda nyata hal ini mungkin dikarenakan wadah yang digunakan cukup baik sehingga tidak menggangu proses fisiologis ikan sehingga pemanfaatan makanan, kemampuan ikan memanfaatkan oksigen dan kelangsungan hidup tidak mengalami penurunan. Tingkat kelangsungan hidup masih cukup baik walaupun dengan jarak tempuh dan lama perjalanan 24 jam, hal itu dikarenakan adanya peranan probiotik yang dapat memperbaiki kualitas air. Kematian yang terjadi pada pemeliharaan setelah pengangkutan banyak terjadi pada hari kedua, hal ini mungkin disebabkan karena ikan masih mengalami stress dan tidak dapat bertahan setelah dipindahkan ke akuarium.

\section{Kualitas Air}

Berdasarkan pengukuran kualitas air yang dilakukan selama percobaan pada setiap perlakuan masih berada dalam batas toleransi untuk kelangsungan hidup ikan nila.

Kondisi kualitas air yang mendukung kelangsungan hidup ikan sebaiknya tetap dipertahankan selama pengangkutan, tetapi hal ini akan sulit untuk dilakukan, sehingga salah satu cara yang dapat dilakukan ialah mencoba meminimalkan faktor-faktor yang menjadi penyebab utama kematian ikan pada saat pengangkutan, diantaranya mengurangi laju metabolisme yakni pengangkutan ini dilaksanakan pada suhu yang rendah.

Kondisi suhu pada saat penelitian ini berkisar antara 23-24 ${ }^{\circ} \mathrm{C}$. Kisaran suhu ini sangat ideal untuk mendukung pengangkutan. Pada suhu yang rendah akan mengakibatkan aktifitas metabolisme rendah dan konsumsi oksigen juga berkurang, sehingga dapat mengurangi tingkat mortalitas pada benih ikan selama proses pengangkutan. Hal ini sesuai dengan yang dikatakan oleh Saanin (1975) bahwa pada suhu yang rendah intensitas reaksi kimia rendah, aktifitas fisiologi rendah, kebutuhan oksigen untuk respirasi rendah sehingga $\mathrm{CO}_{2}$ yang dihasilkan juga rendah serta kelarutan oksigen tinggi.

Konsentrasi oksigen terlarut (DO) adalah salah satu parameter kualitas air yang sangat penting. Rendahnya oksigen biasanya merupakan penyebab utama kematian ikan secara mendadak dan dalam jumlah yang sangat besar. Jumlah DO dari hasi penelitian berkisar antara 6,34 - 6,87 ppm, dan DO tertinggi terdapat pada tingkat kepadatan 400 ekor / 5 liter sebesar 6,87 ppm. Mempertahankan kondisi oksigen terlarut dalam kondisi normal akan membantu mempertahankan kesehatan ikan. Jika konsentrasi oksigen terlarut tidak dapat dipertahankan, ikan akan mengalami stress, mudah terserang penyakit bahkan dapat mengalami kematian (Stickney, 1979). 
$\mathrm{NH}_{3}$ merupakan racun bagi ikan, konsentrasi $\mathrm{NH}_{3}$ dalam air yang ideal bagi kehidupan ikan adalah tidak boleh melebihi 1 ppm (Wardoyo, 1975). Kisaran $\mathrm{NH}_{3}$ tertinggi terjadi pada tingkat kepadatan 500 ekor / 5 liter yaitu mencapai 0,030 ppm.

Menurut Boyd dan Lichkoppler (1979), kebanyakan ikan dapat mentolerir kadar karbondioksida sampai $60 \mathrm{ppm}$. Kisaran $\mathrm{CO}_{2}$ pada akhir penelitian tertinggi terjadi pada kepadatan 300 ekor / 5 liter yang mencapai 2,96 ppm, sedangkan kisaran $\mathrm{CO}_{2}$ pada perlakuan $\mathrm{B}$, dan $\mathrm{C}$ adalah 1,89 ppm. Tingginya $\mathrm{CO}_{2}$ terjadi akibat rendahnya kadar $\mathrm{pH}$ air. Hal ini sesuai dengan yang dikatakan oleh Boyd (1982) kadar $\mathrm{CO}_{2}$ dapat dipengaruhi oleh $\mathrm{pH}$, pada saat kandungan $\mathrm{pH}$ rendah maka $\mathrm{CO}_{2}$ tinggi, demikian pula sebaliknya.

Kisaran Kualitas air pada proses pengangkutan dengan kepadatan 300 ekor / 5 liter, 400 ekor / 5liter, 500 ekor / liter masih cukup baik untuk untuk lama pengangkutan 24 jam, hal tersebut dikarenakan salah satu fungsi dari probiotik yaitu memperbaiki kualitas air dari sisa metabolisme ikan.

\section{KESIMPULAN}

Kelangsungan hidup tertinggi pada proses pengangkutan benih ikan bawal air tawar selama 24 jam adalah pada padat penebaran 300 ekor / 5 liter dengan SR sebesar 95,88\%. Kisaran kualitas air masih cukup baik untuk proses pengangkutan selam 24 jam

\section{DAFTAR PUSTAKA}

Boyd CE, Lichkoppler. 1979. Water Quality Management in Pond Fish Culture. Research and Development Series No. 22. International for Aquaculture. Agriculture Experiment. Station. Auburn, Alabama.

Eckman R. 1987. Growth and body composition of juvenile Colossoma macropomum Cuvier 1818 (Caracoidea) : Feeding on Artificial

Martin SN, Gunzman EC. 1994. Effect of drying method of bovine biod on the performance of growing diets for Tambaqui Colossoma macropomum Cuvier 1818 (Caracoidea) : Feeding on Atrificial Diets. Aquaculture 124:
Moriarty DJW. 1999. Microbial Biosystem; New Fronties. Dalam: Bell CR, Brylinsky M, Johnson GP (Editor). Proceeding of The $8^{\text {th }}$ International Symposium on Microbial Ecology. Canada.

Stickney RR. 1979. Principles of Warm Water Aquaculture. John Willey and Sons, USA.

Saanin, 1975. Handling and Transportation of Fish Fry. Biotrop, T. C. Induced Breeding Techniques. Bogor.

Verschuere L, Rombaut G, Sorgeloos P, Verstraete W. 2000. Probiotic bacteria as biological control agents in aquaculture. Microbiology and Molecular Biology Reviews, Dec. 2000: 655-671.

Zaenudin M. 2011. Penggunaan Bakteri Probiotik Pada Pengangkutan Benih Ikan NIla (Oreochromis niloticus) Untuk Meningkatkan performans Ternak Kelinci. Karya Ilmiah. Universitas Djuanda Bogor. 